\title{
Upaya Pengendalian Hama Gudang Sitophilus oryzaeL.Dengan Penggunaan Pestisida Nabati
}

\author{
Indriyani Indriyani, Irma Rahmayani dan Dian Wulansari \\ Fakultas Teknologi Pertanian, Universitas Jambi, Kampus Pondok Meja Jl Tribrata Km 11, \\ Jambi, Indonesia
}

E-mail: indriyani@unja.ac.id

\begin{abstract}
ABSTRAK
Tujuan penelitian ini adalah untuk mengetahui pengaruh campuran serbuk pestisida nabati antara daun pandan wangi, sukun dan jambu biji dalam mengendalikan hama gudang Sitophilus oryzae L. serta untuk mengetahui campuran serbuk pestisida nabati yang paling efektif dalam mengendalikan Siotphilus oryzae L. Penelitian ini merupakan penelitian deskriptif dengan melihat pengaruh dari perlakuan berikut P1 : campuran serbuk daun pandan wangi dan daun sukun, P2 : campuran serbuk daun sukun dan daun jambu biji dan P3 : campuran serbuk daun pandan wangi dan daun jambu biji. Parameter dalam penelitian ini adalah kadar air, uji fitokimia secara kualitatif, persentase penolakan, mortalitas, efikasi serta kecepatan kematian. Hasil penelitian menunjukkan pestisida nabati campuran serbuk daun pandan wangi dan daun sukun, daun sukun dan daun jambu biji serta daun pandan wangi dan daun jambu biji berpengaruh sebagai pengendali hama gudang Sitophilus oryzae L. Pestisida nabati paling efektif dalam mengendalikan hama gudang Sitophilus oryzae L. adalah campuran serbuk daun pandan wangi dan daun sukun dengan nilai kadar air 3,04\%, positif mengandung senyawa alkaloid flavonoid, polifenol, dan steroid, persentase penolakan $45 \%$, mortalitas 63,33\%, efikasi 63,33\%, dan kecepatan kematian 4,3 ekor/2 hari.
\end{abstract}

Kata kunci : Serbuk, pestisida nabati, penolakan, mortalitas, efikasi

\section{PENDAHULUAN}

Pengendalian hama gudang Sitophilus oryzae L. dapat dilakukan dengan penggunaan pestisida nabati sebagai senyawa yang ramah lingkungan, dapat menolak atau mengusir hama gudang karena mengeluarkan bau yang tidak disukai oleh hama (Mulyadi, 2007). Menurut Dubey dkk (2010), aktivitas biologi minyak atsiri terhadap hama gudang dapat bersifat menolak (repellent), racun kontak (toxic), racun pernafasan (fumigant), mengurangi nafsu makan (antifeedant), menghambat peletakan telur (oviposition deterrent), menghambat petumbuhan, menurunkan fertilitas, serta sebagai anti hama gudang vektor (Guzman dan Siemonsma, 1999).

Daun pandan wangi (Pandanus amaryllifolius Roxb.) mengandung minyak atsiri yang terdiri dari 6-42\% hidrokarbon seskuiterpen dan 6\% monoterpen linalool, dan $10 \%$ senyawa aromatik berupa 2-asetil-1-pirolin (Guzman dan Siemonsma, 1999). Penelitian sebelumnya juga pernah dilakukan menggunakan daun pandan wangi sebagai pestisida nabati pengendali hama kutu beras (Sitophilus Oryzae L.) yaitu dengan menggunakan distilat minyak atsiri daun pandan wangi. Penelitian yang dilakukan oleh Dede dkk (2007) mengenai uji penolakan kutu beras dari distilat minyak atsiri pandan wangi menunjukkan persen penolakan yang terbaik sebesar 32,22\% untuk konsentrasi $10 \%$. 
Daun sukun (Artocarpus altilis) mengandung saponin, tannin, flavonoid, triterpenoid, sulfur, kumarin dan steroid yang berfungsi sebagai pestisida (Wuri dkk, 2013). Senyawa flavonoid pada daun sukun memiliki sifat insektisida yaitu dengan menimbulkan kelayuan syaraf pada beberapa organ vital hama yang dapat menyebabkan kematian seperti pernafasan (Dinata, 2005). Flavonoid yang bercampur dengan alkaloid, fenolik dan terpenoid memiliki aktivitas hormone juvenile sehingga memiliki pengaruh pada perkembangan hama gudang. Penelitian Dean (2015) membuktikan bahwa ekstrak daun sukun mampu membunuh lalat buah pada konsentrasi terendah yakni 5\% dapat membunuh 53,3\% hewan uji, pada konsentrasi $10 \%$ dapat membunuh $66,7 \%$ hewan uji, pada perlakuan konsentrasi $15 \%$ dapat membunuh $76,7 \%$ lalat buah dan pada perlakuan $20 \%$ ekstrak dapat membunuh $83,3 \%$ lalat buah dari 30 ekor hewan uji.

Daun jambu biji mengandung metabolit sekunder, terdiri dari tanin, polifenolat, flavonoid, monoterpenoid, siskulterpen, alkaloid, kuinon dan saponin (Kurniawati, 2006).Penelitian daun jambu biji telah dilakukan oleh Nuryani et al. (2017), dapat disimpulkan bahwa pengaruh daya antifungi ekstrak daun jambu biji tua (Psidium guajava L.) terhadap pertumbuhan jamur Candida albicans lebih kecil di banding terhadap bakteri Staphylococcus aureus. Persentase daya hambat ekstrak daun jambu biji 25\%, 50\%, 75\% di banding obat klorheksidin untuk jamur Candida albicans adalah; pada 61, 80 dan 88 . Presentase daya hambat ekstrak daun jambu biji muda 24\%, 50\%, 75\% di banding obat klorheksidin untuk bakteri Staphylococcus aureus adalah 105, 116 dan 126.

Penelitian ini mengujikan campuran antara serbuk daun pandan wangi dan daun sukun, serbuk daun sukun dan daun jambu biji serta serbuk daun pandan wangi dan daun jambu biji. Penggunaan campuran serbuk tersebut diharapkan dapat memberikan efek pestisida terbaik dalam menolak dan menghambat perkembangan Sitophilus oryzae L. Menurut Cloyd (2011), aplikasi campuran pestisida ditujukan untuk meningkatkan keefektifannya. Hasil penelitian Dadang dkk (2011) menunjukkan adanya peningkatan keefektifan formula pestisida nabati yang mengandung beragam bahan aktif.

Penelitian ini bertujuan untuk mengetahui pengaruh penambahan pestisida nabati campuran perbandingan 50:50 antara serbuk daun pandan wangi dan daun sukun, campuran serbuk daun sukun dan jambu biji serta campuran serbuk daun pandan wangi dan daun jambu biji sebagai pengendali hama gudang Sitophilus oryzae L. serta mendapatkan jenis campuran serbuk pestisida nabati yang paling efektif dalam mengendalikan hama gudang Sitophilus oryzae L.

\section{METODOLOGI PENELITIAN}

\section{Bahan dan Alat}

Bahan utama yang digunakan dalam penelitian ini yaitu daun pandan wangi tua (hijau pekat, daun ke-8 dari pucuk), daun sukun tua (hijau pekat, daun ke-4 dari pucuk), daun jambu 
biji tua (hijau pekat, daun ke-8 dari pucuk), hama gudang Sitophilus Oryzae L dan beras Topi Koki dengan kadar air $14 \%$.

Alat-alat yang digunakan dalam penelitian ini adalah toples plasik berukuran $12 \mathrm{~cm} \mathrm{x}$ $10 \mathrm{~cm}$,timbangan digital, blender, ayakan 40 mesh, kantong teh (food grade, berukuran $5 \times 5,6$ $\mathrm{cm})$, sealerdan kain kassa.

\section{Pelaksanaan Penelitian}

Penelitian dilaksanakan dengan menggunakan Rancangan Acak Lengkap (RAL) dengan 3 perlakuan yaitu campuran serbuk dari daun pandan wangi dan daun sukun, daun sukun dan daun jambu biji serta daun pandan wangi dan daun jambu biji. Setiap bagian dilakukan 3 kali ulangan sehingga didapatkan 9 satuan percobaan.

Serbuk yang didapatkan ditimbang sesuai konsentrasi dari 100 gram berat beras. Lalu dimasukkan ke dalam kantong teh, kemudian beras dan serbuk yang sudah dikemas dengan kantong teh dimasukkan ke dalam plastik yang sudah berisi hama Sitophilus oryae L. sebanyak 20 ekor yang sudah diadaptasikan selama 7 haridan plastik tersebut dimasukkan ke dalam toples dan ditutup dengan kain kassa. Lalu diamati 2 hari sekali selama 14 hari. Gambaran dari pelaksanaan penelitian ini dapat dilihat pada Gambar 1 berikut.

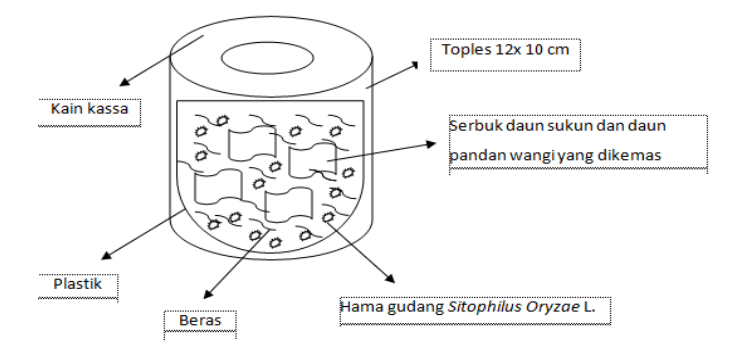

Gambar 1. Aplikasi Pelaksanaan Penelitian

\section{Parameter yang Diamati}

Parameter yang digunakan pada penelitian ini adalah kadar Air (Sudarmadji dkk, 1997), Uji Fitokimia Secara Kualitatif (Harborne, 1984), dan pengamatan terhadap hama gudang Sitophilus oryzae L. yang meliputi :

\section{Persentase Penolakan Hama Gudang Sitophilus oryzae L. (Mardianingsih, 1994)}

Persentase penolakan didapat dari seberapa banyak hama gudang Sitophilus oryzae L. yang berpindah tempat dari plastik ke wadah toples dengan menggunakan rumus:

$$
\% \text { Penolakan }=\frac{\text { Jumlah hama gudang pindah }}{\text { jumlah hama gudang uji }} \times 100 \%
$$


Jumlah Hama gudang Sitophilus oryzae L. Mati (Supeno, 2005 dan Mayasari, 2016)

a. Mortalitas (Patty, 2001 dan Supeno, 2005)

$$
\text { Mortalitas }=\frac{\text { Jumlah hama gudang mati }}{\text { Jumlah hama gudang uji }} \times 100 \%
$$

b. Efikasi (Mayasari, 2016)

$$
\text { Efikasi }=\left(1-\frac{T a}{C a} \times \frac{C b}{T b}\right) \times 100 \%
$$

Keterangan :

Ta : Jumlah kutu beras yang masih hidup setelah aplikasi

$\mathrm{Tb}$ : Jumlah kutu beras yang hidup sebelum aplikasi

$\mathrm{Ca}$ : Jumlah kutu beras kontrol yang masih hidup setelah aplikasi

$\mathrm{Cb}$ : Jumlah kutu beras kontrol yang hidup sebelum aplikasi

c. Kecepatan Kematian Hama gudang Sitophilusoryzae L. (Setiawan, 2014 dan Mayasari, 2016)

$$
V=\frac{\mathrm{T} 1 \mathrm{~N} 1+\mathrm{T} 2 \mathrm{~N} 2+\mathrm{T} 3 \mathrm{~N} 3+\cdots+\mathrm{TzNz}}{n}
$$

Keterangan :

V : Kecepatan kematian (Ekor/Hari)

$\mathrm{T}$ : Pengamatan hari ke -

$\mathrm{N}$ : Jumlah hama gudang yang mati (Ekor)

$\mathrm{n}$ : Jumlah hama gudang yang diujikan (Ekor)

\section{Analisa Data}

Data yang diperoleh dianalisis secara deskriptif dengan melihat pengaruh dari perlakuan.

\section{HASIL DAN PEMBAHASAN}

\section{Kadar Air}

Kadar air ditentukan untuk mengidentifikasi banyaknya air yang terkandung dalam sampel sebagai persen bahan kering.Hasil kadarair daun segar dan serbuk dari daun pandan wangi, sukun, jambu biji serta campuran serbuk dari daun pandan wangi dan daun sukun, daun sukun dan daun jambu biji serta daun pandan wangi dan daun jambu biji dapat dilihat pada Tabel 1 berikut. 
Tabel 1. Hasil analisis kadar air

\begin{tabular}{lcc}
\hline \multirow{2}{*}{ Jenis Pestisida } & \multicolumn{2}{c}{ Kadar Air (\%) } \\
\cline { 2 - 3 } & Segar & Serbuk \\
\hline Sukun & 20,40 & 2,97 \\
Pandan Wangi & 22,67 & 3,10 \\
Jambu Bji & 17,57 & 2,33 \\
Campuran Sukun & 21,53 & 3,04 \\
Pandan Wangi & & \\
Campuran Sukun & 18,98 & 2,65 \\
Jambu Biji & & \\
Campuran Pandan & 20,12 & 2,72 \\
Wangi Jambu Biji & & \\
\hline
\end{tabular}

Berdasarkan Tabel 1diatas dapat diketahui bahwa nilai kadar air daun segar dan campurannya berkisar antara 17,57 - 22,67\% dan nilai kadar air serbuk berkisar antara 2,33 $3,10 \%$. Nilai kadar air serbuk yang rendah disebabkan karena adanya proses pengeringan daun yang dilakukan dalam penelitian ini.Proses pengeringan bertujuan untuk menurunkan kadar air dari serbuk daun yang dihasilkan.Kadar air ditentukan untuk mengidentifikasi banyaknya air yang terkandung dalam sampel sebagai persen bahan kering. Menurut SNI, kadar air dalam serbuk tidak boleh melebihi 10\%. Hal ini bertujuan untuk menghindari cepatnya pertumbuhan jamur dalam serbuk (Soetarno dan Soediro, 1997).

\section{Uji Fitokimia secara Kualitatif}

Uji fitokimia merupakan uji kualitatif kandungan senyawa kimia dalam bagian tumbuhan, terutama kandungan metabolit sekunder yang di antaranya adalah flavonoid, alkaloid, saponin, tanin, terpenoid dan sebagainya (Septyaningsih, 2010). Senyawa-senyawa tersebut merupakan senyawa kimia pertahanan tumbuhan yang termasuk kedalam metabolit sekunder yang dihasilkan pada jaringan tumbuhan dan dapat bersifat toksik serta dapat juga bersifat racun perut dan pernafasan pada suatu hama (Nugraha dkk, 2016).

Hasil Uji fitokimia campuran serbuk dari daun pandan wangi dan daun sukun, daun sukun dan daun jambu biji serta daun pandan wangi dan daun jambu biji dapat dilihat pada Tabel 2 berikut. 
Tabel 2. Hasil Uji Fitokimia

\begin{tabular}{|c|c|c|c|}
\hline \multirow[b]{2}{*}{$\begin{array}{l}\text { Jenis } \\
\text { Senyawa } \\
\text { Kimia }\end{array}$} & \multicolumn{3}{|c|}{ Campuran Serbuk Daun } \\
\hline & $\begin{array}{c}\text { Pandan } \\
\text { Wangi + } \\
\text { Sukun }\end{array}$ & $\begin{array}{c}\text { Sukun } \\
+ \\
\text { Jambu } \\
\text { Biji }\end{array}$ & $\begin{array}{c}\text { Pandan } \\
\text { Wangi } \\
+ \\
\text { Jambu } \\
\text { Biji }\end{array}$ \\
\hline Alkaloid & + & + & + \\
\hline Flavonoid & + & + & + \\
\hline Polifenol & + & + & + \\
\hline Saponin & - & + & + \\
\hline Steroid & + & + & + \\
\hline
\end{tabular}

Berdasarkan hasil uji fitokimia seperti yang terlihat pada Tabel 2, didapat hasil bahwa campuran serbuk daun sukun dan jambu biji serta campuran serbuk daun pandan wangi dan jambu biji positif mengandung senyawa alkaloid, flavonoid, polifenol, saponin dan steroid sedangkan campuran serbuk daun pandan wangi dan daun sukun positif mengandung senyawa alkaloid, flavonoid, polifenol dan steroid namun negatif mengandung senyawa saponin.

Perbedaan hasil uji ini dapat disebabkan karena kemampuan deteksi uji fitokimia yang tidak mampu mendeteksi senyawa metabolit yang berjumlah sedikit didalam serbuk yang digunakan pada penelitian (Oktari dkk, 2014).Kandungan yang terdapat didalam suatu tanaman juga dipengaruhi oleh jenis, suhu, cuaca, lingkungan dan tempat tumbuh tanaman tersebut. Menurut Katno (2008), perbedaan kondisi lingkungan tempat tumbuh juga dapat menyebabkan perbedaan jenis dan jumlah dari metabolit sekunder yang terkandung dalam tumbuhan yang tumbuh di suatu daerah tertentu dengan daerah lainnya.

Persentase Penolakan Hama Gudang Sitophilus Oryzae L.

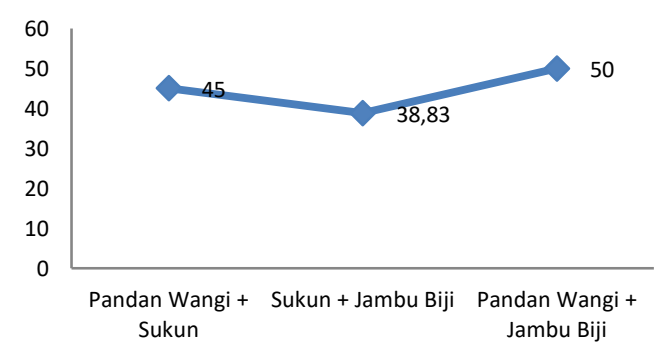

Gambar 2. Tingkat Penolakan \% 
Gambar 2. Persentase Penolakan (\%) hama gudang dengan penambahan campuran serbuk pestisida nabati daun pandan wangi, sukun dan jambu biji

Persentase penolakan hama gudang sithophilus oryzae L. didapatkan dengan mengamati hama kutu beras yang berpindah tempat dari plastik ke toples. Berdasarkan grafik pada Gambar 2 maka dapat diketahui bahwa pestisida nabati campuran serbuk daun pandan wangi dan daun jambu biji lebih efektif dalam menolak hama gudang Sitophilus oryzae L. yaitu sebesar 50\% dibandingkan pestisida nabati campuran serbuk daun pandan dan sukun serta campuran serbuk daun sukun dan jambu biji. Hal tersebut disebabkan karena daun jambu biji juga memiliki kandungan minyak atsiri yang menimbulkan aroma yang khas yaitu komponen minyak atsiri yang disebut eugenol. Eugenol dapat digunakan sebagai fungisida, bakterisida, nematisida dan insektisida (Kurniawati, 2017). Daun pandan wangi mengandung minyak atsiri yang terdiri dari 6-42\% hidrokarbon seskuiterpen, 6\% monoterpen linalool, dan 10\% senyawa aromatik berupa 2-asetil-1-pirolin (Guzman dan Siemonsma, 1999). Campuran dari senyawa minyak atsiri yang memiliki aroma yang khas tersebut bersifat repellent sehingga mengakibatkan banyaknya hama gudang Sitophilus oryzae L. yang berpindah dari dalam plastik ke toples sehingga menghasilkan tingkat penolakan yang semakin tinggi.

\section{Jumlah Hama Gudang Sitophilus oryzae L. yang Mati}

\section{Mortalitas (\%)}

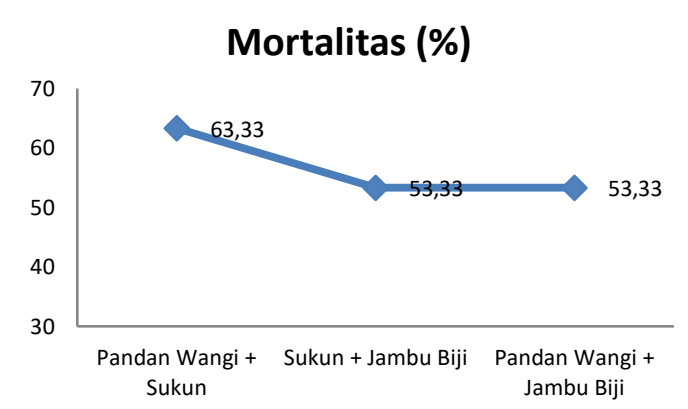

Gambar 3. Mortalitas (\%) hama gudang dengan penambahan campuran serbuk pestisida nabati daun pandan wangi sukun dan jambu biji

Berdasarkan Gambar 3 diatas, maka dapat diketahui bahwa pestisida nabati yang paling efektif dalam mengendalikan hama gudang Sitophilus oryzae L. adalah pestisida nabati dari campuran serbuk daun pandan wangi dan daun sukun yaitu dengan nilai mortalitas sebesar 63,33\%. Pestisida nabati campuran serbuk daun sukun dan jambu biji serta campuran serbuk daun pandan wangi dan jambu biji memiliki nilai mortalitas yang sama yaitu 53,33\%. Tingginya nilai mortalitas yang didapat dari campuran serbuk daun sukun dan daun pandan wangi disebabkan oleh mekanisme kerja pestisida campuran serbuk 2 jenis daun ini lebih baik dibanding campuran serbuk dari jenis lainnya sehingga memberikan hasil yang lebih baik dalam membunuh hama gudang Sitophilus oryzae L. dibandingkan pengaplikasian dengan 2 jenis campuran serbuk pestisida lainnya. 
Retno (2015) menyatakan bahwa perbedaan jenis senyawa dalam suatu pestisida nabati dapat memberikan pengaruh yang berbeda terhadap penghambatan aktivitas makan, dan toksisitas terhadap hama sehingga menyebabkan hama Sitophilus oryzae L. mengalami kematian.

\section{Efikasi (\%)}

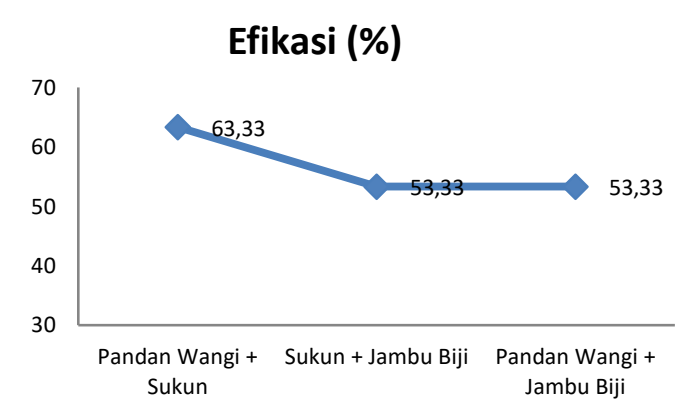

Gambar 4. Efikasi (\%) campuran serbuk pestisida nabati daun pandan wangi, sukun dan jambu biji terhadap hama gudang Sitophilus oryzae L.

Efikasi merupakan tingkat kemanjuran suatu pestisida yang dipergunakan dalam pengendalian populasi hama. Nilai efikasi akan semakin tinggi apabila jumlah populasi hama setelah pengendalian semakin kecil dari populasi hama sebelumnya (Mayasari, 2016).

Berdasarkan data yang didapat, diketahui bahwa nilai efikasi tertinggi didapat dari perlakuan pestisida nabati campuran serbuk daun pandan wangi dan daun sukun yaitu sebesar $63,33 \%$, pestisida campuran serbuk daun jambu biji dan sukun serta campuran serbuk daun jambu biji dan pandan wangi dengan nilai efikasi 53,33\%. Hasil penelitian ini selaras dengan persentase mortalitas dimana mortalitas tertinggi terdapat pada pestisida nabati campuran serbuk daun pandan wangi dan sukun dengan nilai mortalitas sebesar 63,33\% \% yang menyatakan jumlah kematian tertinggi dengan jumlah populasi hama setelah pengendalian terkecil.

Nilai efikasi menunjukkan efektivitas pestisida terhadap organisme sasaran Nilai efikasi sejalan dengan persentase mortalitas, sesuai dengan pendapat Isnaini (2015), suatu pestisda dikatakan efektif apabila memiliki nilai efikasi lebih dari 50\%. 


\section{Kecepatan Kematian (Ekor/2 Hari)}

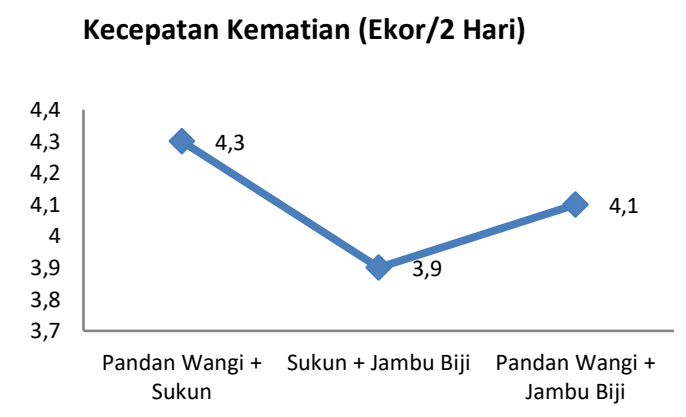

Gambar 5.Kecepatan Kematian (Ekor/2 Hari) hama gudang Sitophilus oryzae L. dari campuran ekstrak pestisida nabati daun pandan wangi, sukun dan jambu biji terhadap hama gudang Sitophilus oryzae L.

Kecepatan kematian menunjukkan seberapa cepat pengaruh pestisida nabati campuran serbuk daun sukun, daun pandan wangi dan daun jambu biji terhadap kematian hama gudang Sitophilus oryzae L. dilihat dari jumlah kematian per harinya (Mayasari, 2016).

Berdasarkan Gambar 5 diatas, maka dapat diketahui bahwa kecepatan kematian paling tinggi didapat dari perlakuan pestisida nabati campuran serbuk daun pandan wangi dan daun sukun yaitu dengan nilai kecepatan kematian 4,3 ekor/2 hari. Hal tersebut dikarenakan jumlah kematian pada perlakuan penambahan serbuk daun pandan wangi dan daun sukun lebih banyak dibanding perlakuan lainnya serta jumlah kematian yang hampir merata pada setiap harinya sehingga setelah dihitung nilai kecepatan kematiannya menghasilkan nilai yang lebih tinggi.

\section{KESIMPULAN DAN SARAN}

\section{Kesimpulan}

Berdasarkan hasil penelitian yang telah dilakukan maka dapat disimpulkan sebagai berikut:

1. Penambahan campuran serbuk daun pandan wangi dan daun sukun, daun sukun dan daun jambu biji serta daun pandan wangi dan daun jambu biji berpengaruh sebagai pengendali hama gudang Sitophilus oryzae L.

2. Jenis pestisida nabati yang paling efektif dalam mengendalikan hama gudang Sitophilus oryzae L. adalah pestisida nabati campuran serbuk daun pandan wangi dan daun sukun dengan nilai kadar air 3,04\%, positif mengandung senyawa alkaloid, flavonoid, polifenol dan steroid, persentase penolakan $45 \%$, mortalitas $63,33 \%$, efikasi $63,33 \%$, dan kecepatan kematian 4,3 ekor/2 hari. 


\section{Saran}

Disarankan menggunakan pestisida nabati campuran serbuk daun pandan wangi dan daun sukun untuk mengendalikan hama gudang Sitophilus oryzae L.

\section{UCAPAN TERIMA KASIH}

Terima kasih diucapkan kepada Fakultas Teknologi Pertanian Dan Lembaga Penelitian dan Pengabdian Kepada Masyarakat Universitas Jambi yang telah mendanai penelitian ini melalui Proyek Penelitian Terapan Unggulan Universitas (PTUU) Tahun 2019

\section{Daftar Pustaka}

Cloyd, R.A. 2011. Pesticide mixtures. In M. Stoytcheva (Ed.) Pesticides-Formulations, Effects, Fate: 69-80. In Tech Europe.

Dadang, E.D. Fitriasari, and D. Pitono. 2011. Field efficacy of two botanical insecticide formulations against cabbage insect pests Crocidolomia flavonana (Lepidoptera: Pyralidae) and Plutella xylostella (Lepidoptera: Yponomeutidae). J. ISSAS 17(2): $38-47$.

Dean, S. V. 2015. Uji Potensi Ekstrak Daun Sukun Artocarpus altilis Sebagai Pestisida Nabati Terhadap Hama Lalat Buah Bactrocera spp. Skripsi Fakultas Teknobiologi. Universitas Atmajaya Yogyakarta. Yogyakarta.

Dede Sukandar, Sandra Hermanto dan Septyani Nurichawati. 2007. Karakteristik Senyawa Aktif Pengendali Hama Kutu Beras (Sitophilus Oryzae L.) Dari Distilat Minyak Atsiri Pandan Wangi (P. Amaryllifolius Roxb.). Prosiding Semirata BKS MIPA Wilayah Barat, FST UIN Syarif Hidayatullah, Jakarta.

Dinata, A. 2005. Tanaman Sebagai Pengusir Nyamuk. PT. Erlangga. Jakarta

Dubey, R.C. \& Saini, S., 2010, Phytochemical and Antimicrobial Studies on essential Oils of Some Aromatic Plants, African Journal of Biotechnology, 9(28), 4364-4368.

Guzman CC and Siemosma SS. 1999. Plant Resources Of South-East Asia, Spices No.13. Bogor.

Harborne, J.B. (1984). Metode Fitokimia Penuntun Cara Modern Menganalisa Tumbuhan. Penerjemah: Kosasih Padmawinata dan Iwang Soediro. Terbitan Kedua. Bandung: Penerbit ITB.

Isnaini. M., Elfira Rosa Pane dan Suci Wiridianti. 2015. Pengujian Beberapa Jenis Insektisida Nabati Terhadap Kutu Beras (Sitophilus Oryzae L.). Jurnal Biota Vol. 1 No. 1 Hal. 18. 
Katno. 2008. Pengelolaan Pasca Panen Tanaman Obat. Jakarta:B2P2TO-OT Badan Penelitian dan Pengembangan

Kesehatan Depkes RI. Hal. 21-37.Kurniawati, A. 2006. Formulasi Gel Antioksidan Ekstrak Daun Jambu Biji (Psidium guajava L.) dengan Menggunakan Auapec HV-505. Skripsi Jurusan Farmasi FMIPA UNPAD.

Kurniawati Enda. 2017. Uji Repelensi dari Serbuk Daun Pandan Wangi (Pandanus Amaryllifolius Roxb) Terhadap Kutu Beras (Sitophilus Oryzae L.) Dan Sumbangsihnya Pada materi Hama Dan Penyakit Pada Tanaman Di Kelas VIII SMP/MTs. Skripsi Program Studi Pendidikan Biologi, Fakultas Ilmu Tarbiyah Dan Keguruan, Universitas Islam Negeri Raden Fatah. Palembang.

Mardianingsih T.L, dkk. 1994. Kemungkinan Produk Nilam Sebagai Bahan Penolak Serangga. Kanisius. Jakarta.Mayasari, E. 2016. Uji Efektivitas Pengendalian Hama Kutu Beras (Sitophilus Oryzae L.) Dengan Ekstrak Daun Pandan Wangi (Pandanus amaryllifolius). Skripsi Fakultas Pertanian, Universitas Muhammadiyah Yogyakarta.

Mulyadi. 2007. Sistem Perencanaan dan Pengendalian Manajemen. Salemba. Empat. Jakarta.

Nugraha, M. N., Nur R., dan yulia M. 2016. Daya repellent ekstrak daun saliara (Lantana Camara L.) dan daun kipahit (Tithonia diversifolia [Hemsley] A. Gray) pada hama gudang Callosobruchus Maculatus F. Jurnal pertanian ISSN 2087-4936 Vol. 7 No. 2.

Nuryani, Siti., R.Fx. Saptono Putro dan Darwani. 2017. Pemanfaatan Ekstrak Daun Jambu Biji (Psidium guajava Linn) Sebagai Antibakteri dan Antifungi. Jurnal Teknologi Laboratorium Vol.6 No.2.Oktari T., Fitmawati Dan Sofiyanti N. 2014. Identifikasi Dan Uji Fitokimia Ekstrak Alami Tanaman Antiurolithiasis. Jurnal JOM FMIPA. Vol. 1. No. 2. Hal. 1-9.

Patty J.A. 2011. Pengujian Beberapa jenis Insektisida Nabati Terhadap Kumbang Sitophylus Oryzae L, Pada Beras. Skripsi Fakultas Pertanian Universitas Pattimura. Ambon.

Retno W, T dan Ninuk H. 2015. Respon Pertumbuhan dan Hasil Tanaman Kedelai Edamame (Glycine max L. Merr.) Pada Berbagai Macam Dan Waktu Aplikasi Pestisida. Jurnal Produksi Tanaman. Vol. 3 No. 6. Hal. 511-517.

Septyaningsih, D. 2010. Isolasi dan identifikasi komponen utama ekstrak biji buah merah (Pandanus conoideus Lamk.). Skripsi. Fakultas Matematika Dan Ilmu Pengetahuan Alam. Universitas Sebelas Maret. SurakartaSupeno, A. 2005. Identifikasi Ketahanan Varietas Kacang Hijau Terhadap Infestasi hama Gudang (Callosobruchus chinensis L.). Skripsi Teknik Pertanian. Universitas Atma Jaya. Yogyakarta. 
Soetarno, S. dan Soediro, I.S., 1997, Standarisasi Mutu Simplisia dan Ekstrak Bahan Obat Tradisional, Presidium Temu Ilmiah Nasional Bidang Farmasi.

Sudarmadji S, dkk. 1997. Prosedur Analisa untuk Bahan Makanan dan Pertanian. Liberty. Yogyakarta.

Supeno, A. 2005. Identifikasi Ketahanan Varietas Kacang Hijau Terhadap Infestasi hama Gudang (Callosobruchus chinensis L.). Skripsi Teknik Pertanian. Universitas Atma Jaya. Yogyakarta.

Wuri N , Djoko A B, Dwi R I . 2013. Uji Potensi Ekstrak Daun Sukun (Artocarpus altilis) Terhadap Lalat Rumah (Musca domestica) Dengan Metode Semprot. Skripsi Universitas Brawijaya. Malang. 